\title{
The Significance of an Educational Game in Teaching Politology
}

\author{
Marina Vasilievna Dvorkovaya ${ }^{1} \&$ Evgeniya Alekseevna Kurenkova ${ }^{1}$ \\ ${ }^{1}$ Moscow Region State University, Moscow, Russia \\ Correspondence: Marina Vasilievna Dvorkovaya, Moscow Region State University, Radio Street, 10a, 105005 \\ Moscow, Russia.
}

Received: February 15, 2015 Accepted: March 16, 2015 Online Published: July 28, 2015

doi:10.5539/ies.v8n8p174

URL: http://dx.doi.org/10.5539/ies.v8n8p174

\begin{abstract}
Game-based learning is being increasingly used in teaching humanities. In teaching politology, it seems to bring the most effective results. Through educational games, learners can fully experience modeling particular situations in the job of a would-be political technologist, which would guarantee training professional politologists with maximum effectiveness. Contemporary environment demands the masterly possession of the gaming methodology, as a fundamental one to instilling into a future politician or politologist such qualities as independent thinking, the fast discovery of the optimal solution to a problem, being stress-resistant and preserving the ability to analyze.
\end{abstract}

Keywords: an educational game, politology, methodology, interactive learning technologies

\section{Introduction}

In the modern post-industrial society the role of a teacher has to change, being not only that of a knowledge-translator but also-of an experience translator. Since the demand to possess a broad outlook, to have uniform standard requirements to all students and the tradition of indisputable authority of a teacher have been replaced by the opportunity to choose subjects, narrow specialization and striving for a concrete result, the role of a teacher has become more that of a consultant.

The entire approach to the algorithm of gaining knowledge has itself changed. The growing pressure of social influences makes traditional teaching methods problematic in perception. The number of children that reveal the so-called syndrome of an autistic-type disorder has notably grown. This tendency has become pandemic in the recent thirty years. It caused the UNO to formally establish April, the 2nd, 2008 as the international Day for promoting the information about autism. In our country, though with a slight lag, a dramatic increase in the number of children with special needs in education has been registered, too. Which makes the issue of the forms that education and socialization should take not only a relevant one, but one of the top priority.

Russia has long been actively seeking effective educational technologies. The contribution of the Soviet era researchers is undeniable in this field. A. S. Vygotsky, A. N. Leontiev, G. P. Schedrovitsky and others are the leading names among lots of others, who have all contributed greatly to shaping a most interesting format of educational activity-such as a game. This format of educational environment presumes using interactive means of teaching. Since in a game the concept of «knowledge» is unified into a whole with the concepts of «experience» and «understanding», it brings the possibility to enlarge the traditional forms of learning by gaming technologies, which, when applied to politology subjects, not only provide the studying of the facts, but also affect the emotional side of the student.

Taking into account the demands of the modern Russian society, shaping a new political reality in Russia is an issue at the top of the agenda. Determining the national motto as well as the station of Russia on the global arena, making the society self-aware of its role in global political trends as a whole and each Russian citizen-as an individual, all this poses concrete tasks before the Russian political education doctrine. First of all, it is raising the level of political awareness of the Russians, along with providing them with the skill to navigate the contemporary political space, with the knowledge of the Russian geopolitical interests, it is boosting the patriotic component in their political consciousness, their active engagement in building the New Russia.

\section{Methodology}

The educational game «The essence of a political regime as an operating form of the political system». 
The goal: to shape the basic ideas about the operating mechanism of a political regime as a form of the political system».

The objectives are:

- To shape and learn to use the set of concepts required for the topic «The political regime».

- To examine the effectiveness and the demand for various political regimes for solving intended tasks. (Such as a political crisis, the issues of the survival of an entire civilization, or constucting a democratic state and society, etc.)

- To train the methods of useful modelling a political situation while studying the theme of «The political regime».

- To learn the methods of personal participation in the collaborative analysis of an issue.

The general information on the game:

The game models the process of the effective functioning of different kinds of a political regime in solving particular political matters. The students are offered, using the geometric shape of a circle, to build a graphic scheme of the interactions between an individual, the society and the state in solving the problems of a particular political situation (chosen from a previously discussed list of actual ones). (The participants themselves can form a circle and enact the roles of an individual, the society and the state).

The game has several stages. We must stress the importance of the preparation stage of a business game. This is especially true where the political sphere is concerned. The rapid changes in the political context require employing a thoughtful and adaptive approach to choosing the educational game's format. That is why various elements of the business game can be selected in advance and creatively enhanced, audio and video-tapes can be used, or the materials of the earlier presentations, if they are useful to achieving the intended goal. During the preparation stage the lecturer and the active students of the class settle the format of the educational game, the balance of its components, the use of additional means and materials, compile a step-by-step scenario, establish the guidelines for the game and discuss the extent of the role of the anchorman (preferably, it is one of the students), and give their expectations about the results.

During the opening stage, the goal of the game is specified, students get to know the format and the rules of the game's realm. The lecturer gives to the anchorman the opportunity to establish the set of uniform concepts with other students. The anchorman forms three groups from the class (according to the three components of the exploration: a democratic, an autocratic and a totalitarian regime) and picks a group of experts (who are to help with the process of exploration and provide an expert conclusion on the result). Watch how mini-groups are being formed. It is essential that they should be more or less equal in terms of capabilities. You also need to control the selection for the expert group. Often it looks like only the teacher can perform the function. We find such choice would be counter-productive, since it deprives the students of a valuable experience of a competent analysis of their fellow students' work. It makes sense to come forward with an approximate list of members for each mini-group and for the expert group in advance at the preparation stage.

During the main stage, a few people, not more than three, prepare the information on the main types of a political regime (democratic, autocratic and totalitarian) in the form of brief lectures. The abstracts of the mini-lectures can also be prepared in advance. That would allow prolonging the time for the main procedure of brainstorming. Then the exploration procedures by means of brainstorming are carried out in the groups. This needs to be controlled by the anchorman and the teacher. Quite often help is required regarding the details and nuances of performing the task. The next step is demonstrating the models of how democratic, autocratic and totalitarian regimes would function. The groups delegate their representative(s) to show the results of their inside discussion by means of diagrams, dramatizations or elements of a flash mob. Then follows a collaborative discussion of the results that arose. Then the summative assessment of the work of the groups is done. Such format can also be used, where individual grades (the scores) are given to the groups and for the level of the presentation separately. The originality of the idea and its practical applicability in the political sphere are assessed. Then the experts bring forward their conclusion and give their grades. The grades are summed up. The anchorman summarizes and voices the result. The list of the criteria for assessment and the rules for summing up the grades are better to be settled yet back at the preparation stage. If the anchorman was a student, it makes sense for the teacher to take the initiative after the final results are declared. He directs the final stage of the game. This stage is for providing the feedback (Some Basic Active Learning Strategies). The teacher needs to prepare a list of questions that would fully uncover the educational, didactic, promoting and practical charge of the game. The list has to be different for each group. The answers and offers, after their processing, will give the material for the 
improvements in the future. It makes sense to discuss the choices for further educational games, taking into account the experience of the accomplished one and the political situation in the country. The game lasts 1 hour and 50 minutes.

1) The preparation stage: $10-15$ minutes.

2) The main stage: 1 hour 20 minutes.

a. Mini-lectures: 15 minutes.

b. Group work: 30 minutes.

c. Presenting results from the groups and the discussion: 20 minutes.

d. Presenting the experts' conclusion: 10 minutes.

3) The final stage: 10 minutes.

The overall expected result:

Acquiring the set of notions for the theme of «The political regime»

A shaped idea about the mechanism by which various political regimes function in solving the tasks of political development.

Acquiring the skills of team research work.

\section{Results}

The alignment method of conducting educational games includes four basic stages. The first is the preparation stage, which particularly suggests the most intense contribution from the teacher. He or she thoroughly thinks over the scenario of the intended class, holds meetings to define the theme, the problematic challenge of the game and specifies the goals and objectives for a particular gaming realm. Then, the teacher chooses the set of the concepts to be explored and decides on the most suitable form of conducting the interactive class. He or she needs to specify the contents of the exercising part, prepare the handout materials and analyze the anticipated results. The teacher also needs to decide on the method for selecting the active part of a student group. It is important to introduce such a practice of holding these educational games that students should get accustomed to the idea that they bear the visible basic load of the preparation work themselves.

The effect of the educational game directly depends on the clarity of the specifying instructions from the teacher upon the tasks and objectives of the intended game. This process takes place during the second stage - the opening (introductory) stage. The introduction triggers everyone and gives the primary knowledge on the problem suggested. This is when the teacher (anchorman) informs the students on the rules of group work and specifies the limits (of time, conceptual, communicative).

The third, or main, stage includes the following moments: identifying and bringing forward the stands of the participants, grouping the persons with similar views, creating an educational-communicative space. As if in an incubator, it provokes a conception of new meanings to the points of view of the participants. The participant realizes that he or she is free to choose any tactics for his actions. If the roles within a student research group are clearly identified to the participant, the inner clock and sticking to the rules of the educational game will then allow for generating a unique strategy by the participant on his own, for achieving the goals of the training. An important part of exploring the educational space here is the possibility to use various kinds of performance. It means audio and videotapes. The students can use psychodrama, elements of a flash mob and of a training session. As a result, that leads to the disclosure of the student's creative potential, because the student employs some basic knowledge, skills and competences for the educational game, uses the basic algorithms for building teams and team management, employs the personal psychological and physiological qualities that are fundamental to building professional competencies necessary for a specialist. The teacher's role is watching the group's dynamics in doing that, and depending on the situation, smoothes the moments of psychological strain or allows the situation to develop in its own trend. (Corridoni et al., 2014, pp. 22-45)

The last and the final stage of an educational game is the procedure of providing the feedback. Its implementing necessarily means taking the roles off the students by the teacher and providing feedback after the game itself, as well as after the whole class. The reflections, or the procedure of feedback, take place in two parts. At first, the teacher asks the students to recall the most emotional moments of the concluded training, and then asks to analyze it by answering his/her questions. The questions are usually to touch upon the significance of the theme explored, on the essence of the teaching methods etc. At the end of this stage, it is possible to add to the format voicing the perspective plan for the next educational game. 
We consider the attestation stage as one of the necessary phase in Political Regime as Political System Existence Form Educational Game (the attestation methodology is formed on the basis of Donald Kirkpatrick's model).

\begin{tabular}{|c|c|c|}
\hline Evaluation Level & Result Type & Evaluation methods and forms \\
\hline Students' reaction level & $\begin{array}{l}\text { Participants' Attitude } \\
\text { Like / Dislike. } \\
\text { Easy / Difficult } \\
\text { Ready to go on / Not ready to go } \\
\text { on }\end{array}$ & $\begin{array}{l}\text { Feedback procedure } \\
\text { Mini questionnaire }\end{array}$ \\
\hline Got knowledge and skills level & $\begin{array}{l}\text { Changes in the mastering of } \\
\text { separate Political Regime } \\
\text { educational topic by students: } \\
\text { Learning result: } \\
\text { Mastering the necessary set of } \\
\text { competencies in the development } \\
\text { of educational topics. The } \\
\text { mastering of the conceptual } \\
\text { apparatus on Political Regime } \\
\text { topic } \\
\text { Forming an idea of the } \\
\text { functioning mechanism of various } \\
\text { political regime types in solving } \\
\text { the problems of political } \\
\text { development } \\
\text { Educational result: } \\
\text { Formation of team skills for } \\
\text { acquisition and appropriation of } \\
\text { knowledge and skills. } \\
\text { Developing component: } \\
\text { Formation of skills in a } \\
\text { "brainstorming", the mastery of } \\
\text { representation techniques, } \\
\text { defending his or her point of view. }\end{array}$ & $\begin{array}{l}\text { Piecemeal Evaluation } \\
\text { Descriptors (opinions) * } \\
\text { Intermediate test control. }\end{array}$ \\
\hline Effect level & $\begin{array}{l}\text { Efficient development of the } \\
\text { discipline } \\
\text { Learning result: } \\
\text { Mastering the necessary set of } \\
\text { general education, professional } \\
\text { competencies in the development } \\
\text { of the Political Science discipline } \\
\text { Educational result: } \\
\text { Formed skills in the educational } \\
\text { team. } \\
\text { Developing component: } \\
\text { Formed skills in a } \\
\text { "brainstorming." }\end{array}$ & $\begin{array}{l}\text { Final test. } \\
\text { Using the formula } \\
\mathrm{M}-\mathrm{I}=\mathrm{R} \\
\mathrm{M} \text { (Must)is a list of necessary } \\
\text { competencies under the requirements } \\
\text { of the work Political Science program } \\
\mathrm{I} \text { (Inventory) is an extent assessment } \\
\text { of the acquired knowledge on a } \\
\text { "knowledge - skills" scheme } \\
\mathrm{R} \text { (Requirement) is undigested or } \\
\text { poorly assimilated knowledge, skills } \\
\text { identified by the intermediate and final } \\
\text { attestation) }\end{array}$ \\
\hline
\end{tabular}

* Piecemeal Evaluation Report Descriptors (opinions). 


\begin{tabular}{|l|l|l|}
\hline \multirow{5}{*}{} & Criteria & Max. grade \\
\cline { 2 - 2 } & $\begin{array}{l}\text { A material is available and scientific, the ideas are } \\
\text { disclosed }\end{array}$ & 2 \\
\hline $\begin{array}{l}\text { A qualitative summary of the contents: a clear, competent } \\
\text { speech, structured content of the report; convincing } \\
\text { arguments, the most important concepts, laws are dictated } \\
\text { to record }\end{array}$ & 2 \\
\hline $\begin{array}{l}\text { A visual representation of the material (using diagrams, } \\
\text { blueprints, drawings, presentations) }\end{array}$ & 1 \\
\hline $\begin{array}{l}\text { Using additional literature } \\
\text { Using practical mini-research (including sources) }\end{array}$ & 1 \\
\hline \multirow{2}{*}{$\begin{array}{l}\text { Preparation of questions for the audience (5-7 fixing } \\
\text { questions) }\end{array}$} & 1 \\
\hline $\begin{array}{l}\text { Qualitative responses to questions from the audience on } \\
\text { the topic }\end{array}$ & 1 \\
\hline Clearly stated conclusions & 1 \\
\hline
\end{tabular}

Conducting Political Regime As Political System Existence Form Educational Game for two years in three groups consisting of seven students has allowed us to conclude its effectiveness, on the basis of intermediate and final attestation. In groups where educational games were held, including Political Regime As Political System Existance Form Educational Game, a steady efficiency in passing tests has been recorded, an average of 30\%. There is an increase of teambuilding skills, motivational component of both educational and social activities.

An educational game provides huge possibilities for creating an effective learning space with maximum engagement of the students' creative potential. However, the game itself requires an extended preparation, being a multilevel teaching aid. So, using traditional means and forms of learning makes sense too, such as mini-lectures, short essays on the relevant theme etc. They will help to understand the psychological portrait of the group, estimate its general level, identify its «intellectual core». The preparation of an educational game and including it into the learning process takes place gradually and usually touches upon key moments of the university subject of «Politology».

\section{Discussion}

From 1989, politilogy achieved an institutional stage in its development in modern Russia. The subject of politology has been included into the curriculums of higher education institutions. The politilogy chairs in the leading universities of our country design new programs of the applied spectrum, such as political management, political geography, political imageology and others. Fast and quality preparation of the specialist of a wide political range stands in the agenda.

Interactive methods of teaching, including active-learning games look the most suitable for this purpose.

In such a case, interactive learning methods, which include educational games, seem the most effective.

Interactive learning technologies present such a form of the learning process, which makes it impossible for a student not to participate in group interactive collaborative learning, where everybody contributes to the cognition process. (Kashlev, 2005; Gavronskaya, 2008, pp. 101-104).

An educational game is a form of interactive learning. An educational game - is a method for learning new material and polishing professional competencies. It is the broadest concept that unites all game-based forms of interactive learning (Okolelov, 1990, pp. 45-50). The key objective here is to gain new knowledge. It means both skill, which is mechanical knowledge, and proficiency, which is «awareness and experience in one sphere or another» (Ptrovsky \& Yaroshevsky, 1994, p. 494). An educational game differs from a business game, in the way that it is precisely acquiring new knowledge, while a business game reproduces objects and social aspects of a profession, models a system of links within a certain practice.

In the educational process, entertaining, dramatizing, business, role play, computer games are used. G. K. Selevko highlights the following types of educational games: «objective, story-telling, role play, business games and dramatizations». The classification is given here on the basis of the gaming methodology. For instance, a 
business game is a form of simulating objective and social context of a professional activity, modeling the systems of relations, specific for a practice. Various modifications of a business game are usually employed, such as «imitating, operational, a role play, a business theatre, psycho- and sociodrama» (Selevko, 1998, p. 256).

A business game is perceived as a popular form of interactive learning, and of an educational game, in particular. Within its range such teaching methods can be realized as: case studies, the method of incident, brainstorming, the shuttle method, the method of immersion (Sorokina, 2014, p. 224). A business game responds to every methodological requirement to teaching politology.

A business game being a kind of educational game, in essence, constructs the practicum. It fully discloses the main functions of the practicum. The experience that the learner gets through educational games, is highly personalized, bears a lot of emotion, and thus allows to actively assimilating the new knowledge on the subject (Fokin, 2008, p. 240). It gives the opportunity to model the working situations, where a politologist is required to elaborate clear recommendations on solving complicated social and political jigsaws.

The teaching function is enabled through organizing active creative learning of practical and theoretical issues. Within the realm of game future political technologists acquire an active civil stand, which presumes possessing an algorithm for political growth and self-education.

The didactic function is realized by connecting theoretical and practical knowledge, cultivating habitual behavior patterns, by learning to defend the student's own angle of view for the political issues in question.

As the preparedness for such classes is checked, that is, to the future practical aspects, as well as the quality of the independent work, thus the testing function of the practicum is realized (Argunova et al., 2005, p. 106).

The educational game as a means of interactive learning has become one of the modern trends in the development of active learning technologies. Speaking of the differences between active and interactive learning, the scientists stress organizing relationships between the students: interaction prevails over influence. An educational game as an active form of teaching has a range of advantages before the passive forms (Panina \& Vavilova, 2008, p. 176). It is based on emotionally colored communication between the students themselves and between them and the teacher. Knowledge comes through exploration and is not offered as the absolute truth. The entire process of cognition comes as a sequence of educative situations. The problems, that an educational game poses, are solved as a result of collaborative actions of the teacher and the student, therefore, the student is learning how to communicate and to conduct a search along with his or her group (Kurenkova, 2014, pp. 46-50; Biggs, 2003, p. 357). We, in fact, can model particular situations in the work of a future political technologist, which would provide the maximal effectiveness in training professional politologists.

Interestingly, how using game-based methods of learning employs rather a big gap between theory and practice, which reflects the reality and thus helps to fit the learning process into the contemporary context of the real life of the students. Active and imitating learning techniques are such forms of holding classes, where learning and exploration activities aim at imitating professional activity. "We do not offer some information about the profession plus a little bit of activity but we imitate the profession, with regard to the information" (Mukhina, 2013 , p. 97). A business game, as a kind of an educational game, can be characterized as an active method of learning, that allows imitating typical real life situations in a game, where the participants are required to discover their course of action, work out and implement a chain of solutions with checking them for being optimal (Dvorkovoy, 1991, p. 72). This method is in high demand for multi-level analysis of the socio-political situation in the future job of a political consultant.

Educational games presume a change in the communication field «the teacher v. the student». Equal participation of the parties of the cognition process becomes a high priority. There is no indisputable authority of the teacher, there is a subtly molding role of a tutor-there is guidance. (Samir \& Randa, 2012, pp. 48-51). The functions of the teacher change. The learner and the teacher interact on a two-way basis. The teacher is not only to set the goals and objectives of a future lesson, and prepare the teaching aids, but is responsible for creating the independent learning space of the students (Killen, 2007, pp. 336). The teacher is to attentively react at the inside process of political exploration and to tactfully direct them, as well as correct them in case an unexpected failure. Thus a field is created where the students can actively deploy their research striving, which predetermines successful work within a team of political technologists, who are to conduct various political campaigns.

It should be remembered that organizing a game-based learning space should follow certain guidelines. A class is a place of mutual learning, both parties are equal in the activity. Everybody has a right to present and promote and insist on their point of view upon every issue that arises. Only the idea can be criticized. Only an idea and any word can-and should-serve as the cause to collective considering (Kruglikov et al., 2006, p. 189). During 
the game-based classes students get involved into the learning process even without intending to do so, moreover-continually. An educational game means distributing specific roles between the students, which they begin to become deeply aware of. If the script of the lesson has exact and interbalanced roles, it will allow for the atmosphere of expressing thoughts and ideas openly, considering the situations in a creative way, and prepare the participants to defending their standpoints in a theoretical debate. The striving for discovering the optimal solution to the chosen task becomes a powerful stimulus to working out collaboratively the algorithms that would confirm or refute the initial individual ideas (Kiili et al., 2014, pp. 367-377).

\section{Conclusion}

Using a competency approach in contemporary higher education stresses the results of education. A competency means the readiness of a person to employ his or her knowledge, skills and outside resources for proving effective in a real life situation. Comparing different definitions of «the results of education», one can notice that each time one must be able to specify (in a written form) what a successful student is expected to do as an outcome of education. The general point in every definition is one key moment: we must try to achieve a greater precision in specifying what exactly a student will gain, after a teaching episode has concluded, for him, successfully (in terms of knowledge, skills andlor competencies). It is important that the outcomes of education should be related to the student's achievements, not to the teacher's intentions, which are expressed in the objectives of education.

Therefore, in contemporary Russian education we observe a transition from the traditional ways of assessing and reflecting the results of education, which are typically focused on the "input data" (the amount of learning hours or the number of didactic units), to the methods focusing on the "output data" (which use the outcomes of education and the competencies that must have been formed). In other words, the result is stressed (what a student will be able to do), not the contents (what was being taught) (Adam, 2005, p. 102). That is one of the major changes in the learning process, to do with the introduction of the competency approach.

In the practice of modern European higher education, the CA-system (constructive alignment (CA) system) has become widely acknowledged, also called the conception of constructive alignment, devised by J. Biggs. This system is primarily aimed at the optimization of a university learning process (namely: of assessment, of the teaching and of the intended outcomes of education). As it is clear from its name, two aspects are highlighted in it: the constructive and the aligning.

The constructive aspect is determined by the ideas of psychological constructivism. Constructiveness means viewing the learning process as being student-centered, not teacher-centered, and underlines the importance of the fact that students should construct the meaning and knowledge themselves. One of the main axioms here is that knowledge cannot be given, it has to be constructed by the learners themselves (Lefransua, 2005, p. 416). In the CA-system, according to J. Biggs, «the constructive aspect reveals itself in the idea, that students construct the meaning by the relevant learning activity. Thus, the meaning is not something transmitted or given from the teacher to the student, but the student creates it himself/herself. Teaching is only there to analyze the process of learning» (Biggs).

The aligning aspect is revealed in the actions of the teacher, who shapes the educational environment which supports the learning activity that would lead to achieving the intended outcomes of education. The most important part here is that the components of the teaching system (i. e. the teacher's activity), particularly the methods of teaching and the means of assessment), are aligned and consistent with the activity of learning (i. e. with the student's activity, aimed at achieving intended outcomes).

The central place in the learning process, based on the constructive alignment, belongs to the intended outcomes of education (Assessment Resource Centre, n.d.). The latter are formed by means of themes listed in the curriculum, and the understanding of them is fixed as certain goals for the student, such as: "be able to solve certain problems", "possess a skill to something", and others. Education consists of such teaching/learning activities, which provide to the student the opportunity to be characterized by certain target terms. The assessment presumes a choice of: 1) formats (written examinations, presentations, practicum, etc.) and 2) criteria for yielding a single final grade.

The first stage of the implementation of the learning process, the intended learning outcomes is firmly identified. As Biggs notices, first of all, we must separate the functional knowledge from the declarative knowledge. The declarative knowledge is "all the facts, information and experience, that are a part of known" (Lefransua, 2005, p. 416)-it is called so, because one can state it, "declare" in an oral or written form. Students must put the declarative knowledge to work, that is-make it function. Most students cannot succeed in the task of transforming the declarative knowledge into functional on their own. So, the first step in identifying the 
outcomes is to specify what level of understanding is required from the student for each of the themes included in the curriculum, because namely the understanding provides the transformation of the declarative knowledge into functional, and consequently, a competent behavior in one or another professional situation or context.

Secondly, we choose the character of the teaching/learning activity. In Bigg's opinion, lectures and tutorials alone are not sufficient to provide the level of comprehension, at which the target terms can be used. The process of learning needs to be activated, to become an activity, to which purpose the following means can serve: organizing an interactive group learning process beyond the classroom, tightly connecting the learning process to the professional needs, using the educative opportunities of the environment and others. A wide range of effective learning strategies can be employed here, known in the practice of higher education, with a special emphasis put on applying educational games in the learning process (Biggs).

We often hear now, that the contemporary Russian politics is, essentially, gaming. Roughly, it implies that the initial meaning is replaced by a desired one, with an obligatory interception of the strategic initiative. The politics in a game and gaming in the politics have always been in demand and even traditional. Contemporary environment demands the masterly possession of the gaming methodology, as a fundamental one to instilling into a future politician or politologist such qualities as independent thinking, the fast discovery of the optimal solution to a problem, being stress-resistant and preserving the ability to analyze. Which would guarantee the survival of individuals, of the society, of the state and of the entire world. Therefore, the first brick into the cognitive project in Russia can be precisely the thorough elaboration of applying the educational game in the learning process in general, and in teaching politoligy subjects, in particular.

\section{References}

Adam, S. (2005). Using the intended outcomes. The Bolognya process: Being in the mid-way. Moscow: The research center for the problems of quality preparation of professionals, The New Russian University.

Argunova, H., Zhukov, R., \& Marichev, I. (2005). Active teaching methods, a methodological guide. Moscow: The research center for the problems of quality preparation of professionals.

Assessment Resource Centre. (n.d.). The Place of Assessment in the Curriculum: Constructive Alignment. Retrieved December 9, 2014, from http://www.polyu.edu.hk/assessment/arc/assessment/place.htm

Biggs, J. (2003). Teaching for quality learning at university (3rd ed.). Buckingham: Open University Press, Society for Research into Higher Education.

Biggs, J. (n.d.). Aligning teaching for constructing learning. Retrieved December 7, 2014, from https://www.heacademy.ac.uk/sites/default/files/resources/id477_aligning_teaching_for_constructing_learni ng.pdf

Corridoni, T., Kocher, U., \& Reggiani, L. (2014). Education for sustainable development and game theory. Perspectives in Science, 2(1-4), 22-45. http://dx.doi.org/10.1016/j.pisc.2014.08.001

Dvorkovoy, V. (1991). The methodology of a business game. Organizing work and managing a crew of machines at building a ground fundament for a road. Moscow.

Fokin, J. (2008). The theory and the technology of education: The activities approach. A guidance for the students of higher education institutions. Moscow: Academia.

Gavronskaya, J. (2008). Interaction and interactive education. Higher education in Russia, 7, 101-104.

Kashlev, S. (2005). The technology of interactive education. Minsk: Belorussky verasien.

Kiili, K., Lainema, T., Freitas, S., \& Arnab, S. (2014). Flow framework for analyzing the quality of educational games. Entertainment Computing, 5(4), 367-377.

Killen, R. (2007). Effective Teaching Strategies: Lessons from Research and Practice. South Melbourne: Vic., Thompson Social Science Press.

Kruglikov, V., Platonov, E., \& Sharanov, J. (2006). Business games and other methods of acticating cognition. Saint Petersburg.

Kurenkova, E. (2014). The use of educational games in teaching the subjects of history and culturology. Teaching and upbringing: Methods and practice. Proceedings of the $13^{\text {th }}$ international conference on science and practice. Novosibirsk: The ZRNS publishers.

Lefransua, G. (2005). Applied pedagogical psychology. SPb: Prime-EVROZNAK.

Mukhina, T. (2013). Active and interactive educational technologies (formats for holding classes) in higher 
education level. A guidance. N. Novgorod: NNGASU.

Okolelov, O. (1994). The modern technologies of the university education: The essence, devising principles and trends. Higher education in Russia, 2, 45-50.

Panina, T., \& Vavilova, L. (2008). The modern ways to activate learning. Moscow: Academia.

Petrovsky, A., \& Yaroshevsky, M. (1990). Psychology: A Dictionary (2nd ed., corrected and revised). Moscow: Politizdat.

Samir, N., \& Randa, E. (2012). Educational Games: Do They Make a Difference? Procedia-Social and Behavioral Sciences, 47, 48-51.

Selevko, G. (1998). A guide to modern educational technologies. Moscow: Narodnoye Obrazovanie.

Some Basic Active Learning Strategies. (n.d.). Retrieved December 6, 2014, from http://www1.umn.edu/ohr/teachlearn/tutorials/active/strategies/index.html

Sorokina, H. (2014). The disputable issues of studying the history of Russia of the XX century. For grades 10-11. Moscow: VAKO.

Spiller, D. (n.d.). Assessment: Feedback to promote student learning. Retrieved December 6, 2014, from http://www.waikato.ac.nz/tdu/pdf/booklets/6_AssessmentFeedback.pdf

\section{Copyrights}

Copyright for this article is retained by the author(s), with first publication rights granted to the journal.

This is an open-access article distributed under the terms and conditions of the Creative Commons Attribution license (http://creativecommons.org/licenses/by/3.0/). 